\title{
ARISTOLOCHIC ACIDS FROM ARISTOLOCHIA BRIDGESII, A HOST-PLANT OF BATTUS POLYDAMAS ARCHIDAMAS
}

\author{
ALEJANDRO URZÚA*, ROCÍO SANTANDER, GASTÓN SOTES
}

Laboratorio de Química Ecológica, Facultad de Química y Biología,

Universidad de Santiago de Chile, Casilla 40, Correo 33, Santiago, Chile.

(Received: April 6, 2009 - Accepted: July 21, 2009)

\begin{abstract}
The present study confirms the hypothesis that aristolochic acids are present in Aristolochia bridgesii. The chemical composition of aristolochic acids in this species is qualitatively similar to that of Aristolochia chilensis, with the two species differing only in the total amount of aristolochic acids present, and in the relative proportions of each aristolochic acid. These results are consistent with the fact that the two Aristolochia species in Chile both serve as host plants to Battus polydamas archidamas (Lepidoptera, Papilionidae, Troidinii).
\end{abstract}

Keywords: Aristolochia bridgesii; Aristolochia chilensis; Aristolochiaceae;Aristolochic acids; Battus polydamas archidamas, Papilionidae, Troidinii

\section{INTRODUCTION}

Two species represent the family Aristolochiaceae in Chile: Aristolochia chilensis Bridges ex Lindl. and Aristolochia bridgesii (Klotzsch) Duch. Whereas Aristolochia chilensis is found between Caldera in Northern Chile $\left(27^{\circ} \mathrm{S}\right)$ and the south of Santiago $\left(34^{\circ} \mathrm{S}\right)$, the distribution of Aristolochia bridgesii is more restricted, ranging from Vallenar $\left(28^{\circ} \mathrm{S}\right)$ to the south of La Serena $\left(30^{\circ} \mathrm{S}\right)$ at altitudes of $950-1300 \mathrm{~m}$ above sea level ${ }^{1}$. Exceptionally small, isolated populations of this species, sometimes co-existing with $A$. chilensis, are also found on the coast near the latitude of Valparaíso $\left(32^{\circ} 30^{\prime}\right.$ $\mathrm{S})$. In recent years, due to a systematic decrease in rainfall in the region, the populations of Aristolochia bridgesii have fallen significantly, and the plant is now considered a rare species ${ }^{1}$.

Among papilionids, the neotropical genus Battus is monophagous, feeding only on plants of the genus Aristolochia at the larval stage ${ }^{2,3}$. Battus polydamas archidamas Boisd. (Papilionidae, Troidini), the only representative species of the genus in Chile, uses the two Aristolochia species in Chile as host-plants ${ }^{4}$.

Aristolochic acids (AAs) are among the plant signals used by females of Aristolochia-feeding papilionids during the contact and evaluation phase in the search for a host; the signals help the papilionids find a suitable site for oviposition $^{5,6}$. We have recently found evidence that a mixture of aristolochic acid -I (AA-I (1)) and aristolochic acid -II (AA-II (2)) is involved in the recognition of an artificial diet by the first-stage larvae of Battus polydamas archidamas Boisd., and that it has a phagostimulatory effect throughout the larval development ${ }^{7}$.

These findings suggest that AAs are also present in A. bridgesii, and that their chemical composition should be similar with those of $A$. chilensis. This supposition has never been validated, because, of the two species of the Aristolochiaceae family present in Chile, only A. chilensis has been studied and AA-I (1), AA-II (2), AA-IV (4), AA-Ia (5), AA-IIIa (6), and AA-IVa (7) have been identified from the leaves and stems ${ }^{8-10}$.

In addition, there is a nearly complete lack of information on the chemical composition of AAs in the host plants of Aristolochia-feeders. For example, the chemical composition of AAs is known for only five of the 29 species of Aristolochia reported to be host plants for Battus polydamas (Linnaeus) ${ }^{11-13}$.

The above considerations led us to investigate the presence and chemical composition of AAs in Aristolochia bridgesii, and to compare these results with results from $A$. chilensis. In the present communication we compare the chemical composition of AAs in these two species and suggest a reason for the absence of phenolic acids reported in other species of the Aristolochia genus.

\section{EXPERIMENTAL}

\section{Plant material}

Representative samples of aerial parts of Aristolochia bridgesii (Klotzsch) Duch. and Aristolochia chilensis Bridges ex Lindl. were collected during the flowering season in November 2007. The samples were collected from a population in which the two species co-exist, located by Papudo beach (V

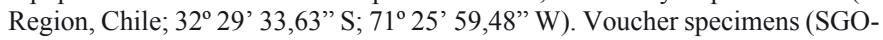
152463 and SGO-152462) were deposited in the Herbarium of the National Natural History Museum in Santiago, Chile.

\section{Extraction of aristolochic acids}

Oven-dried and powdered leaves of A. bridgesii $(200 \mathrm{~g})$ were extracted with $\mathrm{MeOH}$ at room temperature for four days $(4 \times 1.5 \mathrm{~L}$ each $)$. The combined extracts were evaporated in vacuo. The syrupy residue was agitated with 100 $\mathrm{mL}$ of $5 \% \mathrm{NaHCO}_{3}$ for $1 \mathrm{hr}$, allowed to stand for $24 \mathrm{hr}$ at $10{ }^{\circ} \mathrm{C}$, and filtered. The clear filtrate was washed with $\mathrm{CHCl}_{3}(5 \times 50 \mathrm{~mL})$.

Washing with $\mathrm{CHCl}_{3}$ upon evaporation yielded a brown gum that contained no acids, and was not further investigated. The aqueous phase was adjusted to $\mathrm{pH} 2$ with $\mathrm{HCl}$ and extracted with $\mathrm{CHCl}_{3}(5 \times 50 \mathrm{~mL})$. Evaporation of the combined extracts in vacuo yielded a fraction of crude non-phenolic AAs $(239 \mathrm{mg})$. The acid solution was then extracted with AcOEt $(5 \times 50 \mathrm{~mL})$. Evaporation of the combined extracts in vacuo yielded a second fraction of crude phenolic AAs $(356 \mathrm{mg})$. The procedure was repeated with five samples ( $200 \mathrm{~g}$ ) of A.bridgesii obtained from five different plants.

\section{HPLC analysis of aristolochic acids}

The non-phenolic and phenolic AA fractions were analyzed by analytical HPLC (Waters 600), using a reverse-phase Symmetry column (5 $\mu \mathrm{m}$ particle size; $25 \times 0.46 \mathrm{~cm}$ ). Gradient elution was performed using a mobile phase consisting of $0.1 \%$ acetic acid in water (solution $\mathrm{A}$ ) and $0.1 \%$ acetic acid in acetonitrile (solution $\mathrm{B}$ ) as follows: $0-5 \mathrm{~min}$, isocratic elution with $70 \% \mathrm{~A} / 30 \%$ B; 5-45 min, linear gradient from $70 \%$ A / $30 \%$ B to $55 \%$ A / 45\% B. Detection was accomplished with a Waters 2996 diode-array-detector (DAD), and spectra were recorded at wavelengths between 200 and $800 \mathrm{~nm}$. The UV spectra and retention times of all AAs detected were coincident with standards of AA-I (1), AA-II (2), AA-III (3), AA-IV (4), AA-Ia (5), AA-IIIa (6), and AA-IVa (7) previously isolated from A. chilensis, A. argentina, and Battus polydamas archidamas ${ }^{8-10,14}$. Quantification was based on peak areas in chromatograms taken at $254 \mathrm{~nm}$. A dilution series of standard solutions was prepared from stock solutions of standards, and all solutions of standards and samples were stored at $5{ }^{\circ} \mathrm{C}$. Calibration lines were obtained by plotting peak areas against the concentrations of the standards; these lines were used to determine the concentrations of the AAs in the samples. The five collected samples $(200 \mathrm{~g}$ each), taken from five different plants, were analyzed independently.

\section{RESULTS AND DISCUSION}

The aristolochic acids identified in $A$. bridgessi were the same as those found in A.chilensis. Results are shown in Table 1. The only differences between the two species were the total yields of AAs, and the relative amounts of the different AAs. Phenolic components in A. bridgessi accounted for nearly $50 \%$ of the total mixture, while they accounted for only $27 \%$ in A.chilensis. 


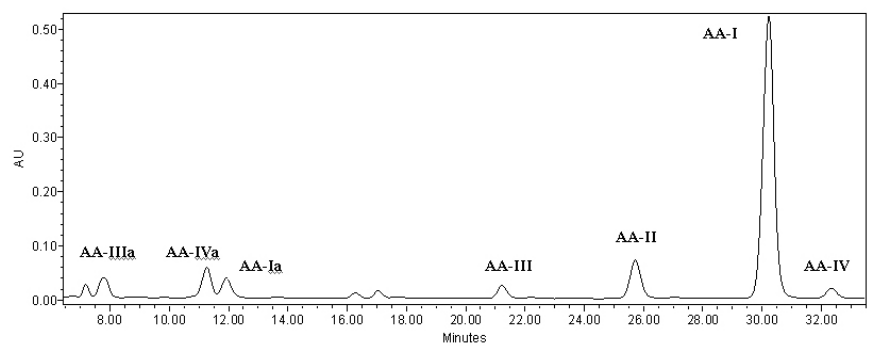

Fig 1. Representative chromatogram of non-phenolic aristolochic acids from A. bridgesii

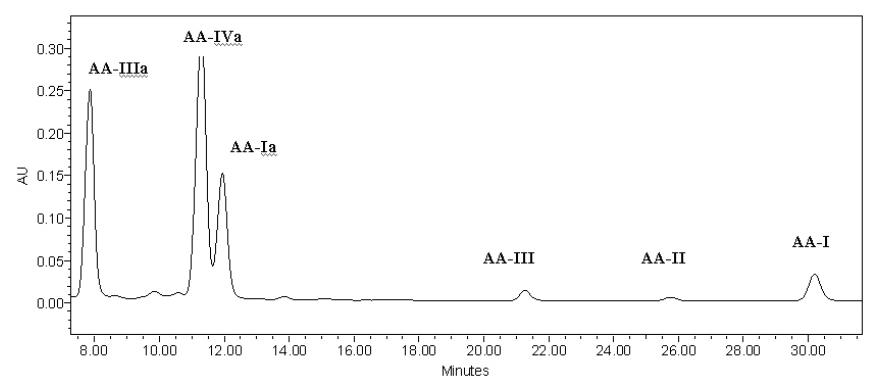

Fig 2. Representative chromatogram of phenolic aristolochic acids from A. bridgesii

Table1.- Aristolochic acid (AAs) from A. bridgesii and A.chilensis

\begin{tabular}{|c|c|c|c|c|}
\hline AAs & $\begin{array}{c}\mathrm{mg} / \mathrm{kg} \text { from } \text { A. }_{\text {bridgesii }^{\text {a }}} \\
\text { IIIa (6) }\end{array}$ & $\begin{array}{c}\mathrm{mg} / \mathrm{kg} \text { from } \\
\text { A.chilensis }^{\text {a }}\end{array}$ & $\begin{array}{c}\mathrm{RT} \\
(\mathrm{min})\end{array}$ & $\mathrm{UV} \lambda_{\text {max }}(\mathrm{nm})$ \\
\hline IVa (7) & $222(17)$ & $49(4)$ & 8.0 & $\begin{array}{c}250,256,301 \mathrm{sh}, \\
358 \mathrm{sh}, 371,386 \mathrm{sh}\end{array}$ \\
\hline Ia (5) & $95(9)$ & $36(5)$ & 10.8 & $\begin{array}{c}220,244 \mathrm{sh}, 254, \\
326,401\end{array}$ \\
\hline III (3) & $15(1)$ & $\operatorname{tr}$ & 12.0 & $\begin{array}{c}221,255,283, \\
312,389\end{array}$ \\
\hline II (2) & $52(5)$ & $118(13)$ & 25.5 & $\begin{array}{c}245 \mathrm{sh}, 255, \\
276 \mathrm{sh}, 299,370\end{array}$ \\
\hline & & & $249,296,362$ \\
\hline I (1) & $436(34)$ & $213(18)$ & 30.5 & $\begin{array}{c}222,258,283, \\
295,322,356,221,250, \\
317,388\end{array}$ \\
\hline IV (4) & $10.5(0.7)$ & $\operatorname{tr}$ & 32.2 & $\begin{array}{c}244 \mathrm{sh}, 251, \\
285 \mathrm{sh}, 315,364, \\
393\end{array}$ \\
\hline
\end{tabular}

${ }^{a}$ mean of five independent analyses (SD in parentheses).

Abbreviations: RT, retention time; tr, trace amounts.<smiles>[R]c1cc(Br)c2cc([N+](=O)[O-])c3c(C(=O)O)cc4c(c3c2c1)OCO4</smiles>

$$
\begin{aligned}
& \mathbf{1} \mathrm{R}_{1}=\mathrm{OCH}_{3} ; \mathrm{R}_{2}=\mathrm{H} \\
& \mathbf{2} \mathrm{R}_{1}=\mathrm{R}_{2}=\mathrm{H} \\
& \mathbf{3} \mathrm{R}_{1}=\mathrm{H}_{i} \mathrm{R}_{2}=\mathrm{OCH}_{3} \\
& \mathbf{4} \mathrm{R}_{1}=\mathrm{R}_{2}=\mathrm{OCH}_{3} \\
& \mathbf{5} \mathrm{R}_{1}=\mathrm{OH} ; \mathrm{R}_{2}=\mathrm{H} \\
& \mathbf{6} \mathrm{R}_{1}=\mathrm{H} ; \mathrm{R}_{\mathbf{2}}=\mathrm{OH} \\
& \mathbf{7} \mathrm{R}_{1}=\mathrm{OCH}_{3} ; \mathrm{R}_{2}=\mathrm{OH}
\end{aligned}
$$

The distribution of AAs in the Aristolochia species studied so far is far from homogeneous. For example, phenolic AAs are not widely distributed in these species, according to two reviews that examine reports of the AA composition of 43 species of Aristolochia up to the year $2003^{11,12}$. This review indicates that AA-I (1) has been observed in 39 species; AA-II (2), 16; AA-III (3), seven; AA-IV (4), eight; AA-IIIa (6), 16; AA-IVa (7), 16; and AA-Ia (5), only two.

The extraction procedure used in the present study allowed the separation of two fractions, one containing phenolic AAs and another containing nonphenolic AAs. Extraction of an acidic solution of AAs with $\mathrm{CHCl}_{3}$ is selective for non-phenolic AAs, with phenolic derivatives present in small amounts as contaminants in the mixture of AAs. To obtain the phenolic derivatives, extraction with $\mathrm{CHCl}_{3}: \mathrm{EtOH}(3: 2)$ has proven to be a good alternative ${ }^{8,10}$. In the present study, extraction with AcOEt proved to be even better method for isolating phenolic AAs from A. bridgesii and A. chilensis.

These observations suggest that the reported absence or low concentrations of phenolic AAs in many plants of the Aristolochiaceae family may be, at least in some cases, the result of inadequate laboratory techniques that led to insufficient extraction of these phenolic components.

Despite this potential limitation of previous studies, it appears from the literature that AA-Ia occurs only in A. chilensis ${ }^{8,10}$ and A. argentina ${ }^{14,15}$. This is somewhat surprising, given the obvious biogenetic relationship with AA-I (1), the major AA in Aristolochia species. Therefore, the presence of AA-Ia (5) may be considered a distinctive biochemical marker of A. bridgesii.

In conclusion, the present study confirms our hypothesis that AAs are present in $A$. bridgesii. The chemical composition of AAs in this species is qualitatively similar to that of $A$. chilensis, with the two species differing only in the total amount of AAs present, and in the relative proportions of each AA. These results are consistent with the fact that the two Aristolochia species in Chile both serve as host plants to B. polydamas archidamas ${ }^{4}$.

\section{ACKNOWLEDGMENTS}

This work was supported by FONDECYT of Chile (grant 1060033).

\section{REFERENCES}

1. P. Riedeman, G. Aldunate, S.Teillier Flora nativa de valor ornamental, Chile, Zona Norte: Identificación y propagación, Corporación jardín botánico chagual, Santiago, Chile, 2006; pp. 292-3.

2. P. Feeny Chemical constraints on the evolution of swallowtail butterflies. In P.W. Price, T. M. Lewinsohn, G.W. Fernandes \& W.W. Benson (eds) Plant-Animal Interactions: Evolutionary Ecology in Tropical and Temperate Regions. John Wiley, New York. 1991; pp. 315-340.

3. J. D. Weintraub,. Host plant association patterns and phylogeny in the tribe Troidini. In J. M. Scriber, Y. Tsubaki \& R. C. Lederhouse (eds) Swallowtail Butterflies: Their Ecology and Evolutionary Biology. Scientific Publishers Inc., Gainesville, Florida, 1995; pp. 307-316.

4. L. Peña, A. Ugarte Las Mariposas de Chile, Editorial Universitaria. Santiago, Chile, 1997; pp. 234-234.

5. R. Nishida, H. Fukami, J. Chem. Ecol. 15, 2549 (1989).

6. K. Sachdev-Gupta, P. P. Feeny, M. Carter, Chemoecology, 4, 19 (1993).

7. C. Pinto, A. Troncoso, A. Urzúa, H. Niemayer, Eur. J. Entomol. 106, 357 (2009).

8. A. Urzúa, G. Salgado, B. K. Cassels, G. Eckhardt, Planta Med. 45, 51 (1982).

9. A. Urzúa, G. Salgado, B. K. Cassels, G. Eckhardt, Collection Czechoslovak Chem. Comun. 48, 1513 (1983).

10. A. Urzúa, R. Rodríguez, B. Cassels, Biochem. Syst. Ecol. 15, 687 (1987).

11. B. D. Mix, H. Guinaudeau, M. Shamma, J. Nat. Prod. 45, 675 (1982).

12. K. V. Poonam, A. K. Prasad, V. S. Parmar, Nat. Prod. Rep. 20, 565 (2003).

13. K. L. Silva-Brandão, A.V.L. Freitas, A.V. Z. Broker, V. N. Solferini, Mol. Phylogenet. Evol. 36, 468 (2005).

14. H. A. Priestap, Phytochemistry, 26, 519 (1987).

15. H. A. Priestap, Phytochemistry, 21, 2755 (1982). 